\title{
Association of TRPS1 gene with different EMT markers in ERa-positive and ERa-negative breast cancer
}

Peng Su${ }^{1}$, Jing Hu${ }^{1}$, Hui Zhang ${ }^{2}$, Ming Jia ${ }^{1}$, Weiwei $\mathrm{Li}^{1}$, Xuanxuan Jing ${ }^{1}$ and Gengyin Zhou ${ }^{1 *}$

\begin{abstract}
Background: Breast cancer is a heterogeneous disease consisting of different subtypes. Trichorhinophalangeal syndrome type 1 (TRPS1) gene, a GATA-type transcription factor, has been found to be highly expressed in breast cancer. Epithelial-to-mesenchymal transition (EMT) is known to play an important role in tumour invasion and metastasis. Our objective was to elucidate the different roles and clinical relevance of TRPS1 in different estrogen receptor (ER) expression subtypes of breast cancer.
\end{abstract}

Methods: An immunohistochemical study was performed. The correlation between clinicopathological features and other biomarker profiles were analysed statistically.

Result: TRPS1 expression was correlated with the patients' age $(P=0.017)$. It was positively related with $E R a(P<0.001)$, progesterone receptor ( $P R)(P<0.001)$ and $E R \beta(P=0.001)$ status, but negatively associated with Ki67 $(P=0.002)$ and HER2 ( $P=0.025)$ status. In ERa-positive breast cancer, TRPS1 expression was positively associated with the expression of E-cadherin ( $P<0.001)$, $\beta$-catenin $(P=0.001)$, ERß $(P=0.03)$, and p53 $(P=0.002)$ status, while in ERa-negative breast cancer, TRPS1 expression was correlated with slug $(P=0.004)$, vimentin $(P=0.003)$, smooth muscle actin (SMA) $(P=0.031)$, and IMP3 $(P=0.005)$ expression.

Conclusions: Based on our findings, we conclude that TRPS1 is positively associated with E-cadherin and $\beta$-catenin status in ERa-positive breast cancer cells, while it is also significantly associated with mesenchymal markers of EMT in ERa-negative breast cancer cells. TRPS1 can be a prognostic marker depending on the type of breast cancer.

Virtual Slides: The virtual slide(s) for this article can be found here: http://www.diagnosticpathology.diagnomx.eu/vs/ 8686515681264281

Keywords: TRPS1, Epithelial to mesenchymal transition, Estrogen receptor, Breast cancer

\section{Background}

Breast cancer is one of the most common cancers in women, accounting for more than $1,300,000$ cases and 450,000 deaths worldwide each year [1]. Breast cancer is a heterogeneous disease that comes in different morphological and immunohistochemical characteristics with corresponding clinical behaviour [2]. The oncogenesis and progression of breast cancer is a complex process involving a variety of transcription factors, activation of oncogenes, and inactivation of tumour suppressor genes $[3,4]$.

\footnotetext{
* Correspondence: zhougy@sdu.edu.cn

${ }^{1}$ Department of Pathology, Shandong University School of Medicine, 44\#, Wenhua Xi Road, 250012 Jinan, Shandong, P.R. China

Full list of author information is available at the end of the article
}

Recently gene expression profiling and immunohistochemistry (IHC) studies have been identified Tricho-rhinophalangeal syndrome-1 gene (TRPS1), a new GATA family member, to be highly prevalent gene in breast cancer $[5,6]$. TRPS is an autosomal dominant genetic disorder characterised by craniofacial and skeletal anomalies due to mutations or deletions of the TRPS1 gene. It is composed of nine zinc finger motifs including a single GATA-type DNA-binding domain flanked by two potential nuclear localisation signals (NLS) and two C-terminal zinc fingers closely related to the domain found in the Ikaros family of lymphoid transcription factors [7]. It has been demonstrated that TRPS1 is a transcriptional repressor and its activities are dependent on both the highly conserved 
GATA DNA-binding domain and the Ikaros-like zinc finger motifs [8]. For example, TRPS1 can repress Stat3 to regulate proliferation and apoptosis of chondrocytes. TRPS1 controls epithelial proliferation through repressing SOX9 in the developing vibrissa follicle in mice. It can also repress the expression of Runx2, a key regulator of osteoblastogenesis and chondrocyte maturation [9]. Moreover, TRPS1 can suppress the osteocalcin expression through binding to its promoter [10].

As mentioned before, TRPS1 gene in human has been found to be overexpressed in breast cancer, expressed in more than $90 \%$ estrogen receptor $\alpha(E R \alpha)$ positive and negative breast cancer subtype [6]. The gene is localised on human chromosome 8q23-24.1, a region highly amplified in several cancers, especially in prostate and breast cancer. It is important to note that TRPS1 gene has been found to be highly expressed not only in the mammary glands but also in prostate, testis, ovaries, kidneys, and lungs [11]. Increasingly, there are more evidences to suggest the involvement of TRPS1 in a variety of functions in human cancers [12-15].

Recent studies have reported that TRPS1 can regulate mesenchymal-to-epithelial transition (MET) during embryonic development in a number of tissues, including kidneys, cartilages, and bones [10,16,17]. Epithelial-tomesenchymal transition (EMT) was first recognised as an important process during normal embryonic development [18]; however, carcinoma cells are also capable of reactivating EMT during tumour progression $[19,20]$. During this transition, tumour cells lose epithelial characteristics such as cell apical-basal polarity, membraneassociated adherents, and cell-to-cell adhesion protein E-cadherin. Concurrently, these tumour cells also undergo a dramatic remodelling of the cytoskeleton to facilitate cell mortality and invasion; the cells are also transformed to obtain a spindle-like phenotype. A key feature of EMT is a gene switch, resulting in downregulation of E-cadherin and upregulation of vimentin, smooth muscle actin. Transcriptional factors, such as snail, slug, and twist, which function by suppressing the expression of epithelial specific adhesion molecules, such as E-cadherin, were unveiled as key regulators inducing EMT in breast cancer and other cancers [21-24]. $\beta$-catenin was first identified as a protein that binds with E-cadherin to maintain cell-tocell adhesion; however, it also functions as a transcription factor. Loss of membranous $\beta$-catenin expression and gain of cytoplasmic or nuclear $\beta$-catenin expression in neoplastic glands have been related to carcinogenesis and tumour progression in gastrointestinal cancers [25,26]. Thus, by detecting these EMT markers, one can roughly estimate the tumour cells undergoing EMT from nonEMT tumour cells.

In addition to the involvement of TRPS1 in regulating MET, it has also been found to repress ZEB2, a key regulator of EMT that inhibits E-cadherin and other epithelial genes [12]. Realizing the potential of TRPS1 gene as the new EMT marker, we focused our work in elucidating different roles and clinical relevance of TRPS1 in $E R \alpha$-positive and ER $\alpha$-negative breast cancer subtypes.

\section{Methods}

\section{Patients and tissue samples}

This study was conducted on 180 paraffin-embedded breast samples, which were histopathologically diagnosed invasive ductal carcinoma during 2007 to 2009 at the Department of Pathology of Qilu Hospital of Shandong University. For using these clinical materials for research purposes, prior patient consent and approvals from the Research Ethics Committee of Shandong Medical University were obtained. All the diagnoses were made following the Pathology and Genetics of Tumours of the Breast and Female Genital Organs of World Health Organisation Classification of Tumours.

\section{Tissue microarray}

For each hematoxylin and eosin (H\&E)-stained slide, two representative areas were selected and the corresponding spots were marked on the surface of the paraffin block. Using a tissue microarray (TMA) punching instrument, the selected areas were punched out and were placed into the recipient block side by side. Each tissue core was $2 \mathrm{~mm}$ in diameter and was assigned with a unique TMA location number that was linked to a database containing other clinicopathologic data [27].

\section{Immunohistochemistry}

The immunohistochemical study was carried out to examine altered protein expression in 180 paraffin-embedded breast tissues as described in previous publications [28]. All the markers were incubated with the sections overnight at $4^{\circ} \mathrm{C}$; the markers included TRPS1 (sc-26974, diluted 1:200; Santa Cruz Biotechnology, CA, USA), P53 (Zhongshan Golden Bridge Biotechnology, ZSGB-Bio, Beijing, China), E-Cadherin (24E10, diluted 1:400, Cell Signalling Technology, USA), mouse monoclonal antibody $\beta$-catenin (E-5, diluted 1:500, Santa Cruz Biotechnology, CA, USA), Vimentin ( D21H3, diluted 1:100, Cell Signalling Technology, USA), slug (C19G7, diluted 1:50, Cell Signalling Technology, USA); the second antibody was from IHC reagent kit (Zhongshan Biotechnology Company, Beijing, China). After diaminobenzidine (DAB) staining, the sections were counterstained with hematoxylin. For negative controls, the antibodies were replaced with phosphate buffered saline (PBS).

\section{Evaluation of immunohistochemical staining}

The stained slides were reviewed and evaluated independently by two observers blinded to patients' information. A 
dual semi-quantitative scale, combining the staining intensity as well as percentage of positive cells, was used to evaluate the protein staining. In brief, staining of TRPS1 was scored semi-quantitatively for intensity $(0=$ no expression, 1 = weak, $2=$ moderate, and $3=$ strong) and percentage of positive cells $(0=0-10 \%, 1=10-30 \%, 2=$ $30-50 \% ; 3=50-80 \%$, and $4=80-100 \%)$. The final score of TRPS1 was the staining score multiplied by the percentage of positive cells. The following cut-off levels were applied: 0 for negative and $\geq 1$ for positive [15]. For $\beta$-catenin, membrane and cytoplasmic/nuclear expression were recorded separately as no staining, weak staining, or strong staining. Cases with more than $50 \%$ of nuclei stain were considered nuclear staining while cases with more than $50 \%$ of cytoplasm stain were considered cytoplasmic staining [29]. ER or PgR was positive if $1 \%$ of tumour cell nuclei were immuno reactive [30]. For other molecular markers, tumours were regarded as immunepositive if $>10 \%$ of tumour cells showed immunoreactivity. Cytoplasmic staining was considered positive for vimentin and SMA. Nuclear staining was considered positive for TRPS1, ER $\beta$, slug and P53. Membranous staining was considered positive for E-cadherin.

\section{Statistical analysis}

Statistical analyses were performed using the statistics software package SPSS 18.0 (SPSS, Chicago, IL). Chi-square test or Fisher's exact test were performed to evaluate the correlation between TRPS1 expression and clinicopathologic characteristics, if appropriate. Bivariate correlations between study variables were calculated by Spearman's rank correlation coefficients. Differences were considered statistically significant for $\mathrm{P}$ values $<0.05$.

\section{Results}

Relationship of TRPS1 over-expression with the clinical features in breast cancer

In the analysis of a 180-member TMA, we found positive TRPS1 expression in 93 cases (51.7\%), while 87 tumours (48.3\%) were negative. Table 1 shows no significant correlation between the expression level of TRPS1 and biological factors such as histology grade $(\mathrm{P}=0.903)$, pathological stage $(P=0.646)$, tumour size $(P=0.343)$, lymph node metastasis $(\mathrm{P}=0.443)$, $\mathrm{P} 53$ status $(\mathrm{P}=0.113)$, and IMP3 status $(P=0.618)$. In contrast, we found that TRPS1 expression was strongly correlated with the patients' age $(\mathrm{P}=0.017)$, Ki67 $(\mathrm{P}=0.002), \mathrm{ER} \alpha(\mathrm{P}<0.001)$, progesterone receptor $(\mathrm{PR})(\mathrm{P}<0.001)$, HER2 $(\mathrm{P}=0.025)$, and $E R \beta$ status $(P=0.001)$. Spearman correlation analysis was preformed to confirm further the correlation between TRPS1 expression and patients' age $(-0.179$, $\mathrm{P}=0.016)$; Ki67 (-0.233, $\mathrm{P}=0.002)$, ER $\alpha(0.333, \mathrm{P}<0.001)$, PR (0.31, $\mathrm{P}<0.001)$, HER2 $(-0.166, \mathrm{P}=0.025)$, and ER $\beta$ status $(0.242, \mathrm{P}=0.001)$. We divided the patients into two groups as ER $\alpha$-positive and ER $\alpha$-negative. TRPS1 expression was observed in 69 (65.7\%) of $105 \mathrm{ER} \alpha$-positive patients, while in 24 (32\%) of $75 \mathrm{ER} \alpha$-negative patients.

\section{Relationship of TRPS1 expression with EMT markers in breast cancer}

As TRPS1 may be a critical regulator of EMT during breast cancer initiation and progression, the expression of EMT markers, including E-cadherin, $\beta$-catenin, vimentin, SMA and slug, were stained in human breast cancer TMA. Statistical analysis indicated that the immunohistochemical expression of TRPS1 is directly correlated with E-cadherin $(P=0.002)$ and $\beta$-catenin $(P=0.003)$, which was further confirmed by Spearman correlation analysis (E-cadherin: $\mathrm{r}=0.231, \mathrm{P}=0.002$; $\beta$-catenin: $\mathrm{r}=0.221, \mathrm{P}=0.003$ ) (Table 1 ). Moreover, we also found that TRPS1 expression was significantly correlated with slug $(\mathrm{P}=0.019)$, vimentin $(\mathrm{P}=0.022)$ and SMA $(\mathrm{P}=0.039)$; the corresponding Spearman correlation values are $0.186(\mathrm{P}=0.012), 0.171(\mathrm{P}=0.022)$, and $0.154(\mathrm{P}=0.039)$.

\section{Correlation between TRPS1 expression and molecular markers in ERa-positive breast cancer}

We analysed the molecular markers in ER $\alpha$-positive breast cancer. Table 2 shows the expression of TRPS1 is positively associated with E-cadherin $(\mathrm{P}<0.001), \beta$-catenin $(\mathrm{P}=0.001), \operatorname{ER} \beta(\mathrm{P}=0.03)$, and $\mathrm{p} 53(\mathrm{P}=0.002)$ status (Figure 1). However, the TRPS1 expression is not associated with slug $(P=0.549)$, vimentin $(P=0.296)$, SMA $(\mathrm{P}=0.296)$, and IMP3 $(\mathrm{P}=0.605)$.

\section{Correlation between TRPS1 expression and molecular markers in ERa-negative breast cancer}

For ER $\alpha$ negative breast cancer cases, Table 3 shows that the immunohistochemical expression of TRPS1 has correlation with slug $(P=0.004)$, vimentin $(P=0.003)$, SMA $(\mathrm{P}=0.031)$, and IMP3 $(\mathrm{P}=0.005)$, which was further confirmed by Spearman correlation analysis (Figure 2).

\section{Discussion}

Breast cancer is a heterogeneous disease consisting of multiple molecular subtypes. The presence of hormone receptors ER, PR, and human EGFR-2 (HER-2) are significantly meaningful in therapeutic decision-making for patients with breast cancer. In addition, these factors may also predict the probability of disease relapse. Hormone receptor-positive tumours have favourable outcomes because of their response to endocrine manipulations such as tamoxifen, aromatase inhibitors, or ovarian ablation [31]. Tumours with ER $\alpha$-negative phenotype tend to have poor prognosis, unlike their hormone receptor or HER-2 positive counterparts; hence, such ER $\alpha$-negative tumours lack targeted therapeutics. 
Table 1 Correlation between TRPS1 expression and the clinicopathologic characteristics of breast cancer patients

\begin{tabular}{|c|c|c|c|c|c|c|c|}
\hline \multirow[t]{2}{*}{ Characteristics } & \multirow[t]{2}{*}{$\mathrm{n}$} & \multicolumn{2}{|c|}{ TRPS1 expression } & \multirow[t]{2}{*}{$P$ value } & \multirow{2}{*}{$\begin{array}{l}\text { Spearman } \\
\text { Correlation }\end{array}$} & \multirow[t]{2}{*}{ Value $(r)$} & \multirow[t]{2}{*}{$P$ value } \\
\hline & & Negative & Positive & & & & \\
\hline \multicolumn{8}{|l|}{ Age(y) } \\
\hline$\leq 50$ & 70 & 26 & 44 & 0.017 & & -0.179 & 0.016 \\
\hline$>50$ & 110 & 61 & 49 & & & & \\
\hline \multicolumn{8}{|l|}{ Grade } \\
\hline I & 11 & 5 & 6 & 0.903 & & & \\
\hline$\|$ & 124 & 59 & 65 & & & & \\
\hline III & 45 & 23 & 22 & & & & \\
\hline \multicolumn{8}{|l|}{ Pathological stage } \\
\hline 1 & 49 & 23 & 26 & 0.646 & & & \\
\hline$\|$ & 85 & 44 & 41 & & & & \\
\hline III & 46 & 20 & 26 & & & & \\
\hline \multicolumn{8}{|l|}{ Tumor size } \\
\hline$<2$ & 60 & 26 & 34 & 0.343 & & & \\
\hline$\geq 2$ & 120 & 61 & 59 & & & & \\
\hline \multicolumn{8}{|c|}{ Lymph node metastasis } \\
\hline Negative & 94 & 48 & 46 & 0.443 & & & \\
\hline Positive & 86 & 39 & 47 & & & & \\
\hline \multicolumn{8}{|l|}{ Expression of Ki67 } \\
\hline$\leq 25 \%$ & 62 & 20 & 42 & 0.002 & & -0.233 & 0.002 \\
\hline$>25 \%$ & 118 & 67 & 51 & & & & \\
\hline \multicolumn{8}{|l|}{ Expression of P53 } \\
\hline Negative & 72 & 40 & 32 & 0.113 & & & \\
\hline Positive & 108 & 47 & 61 & & & & \\
\hline \multicolumn{8}{|l|}{ ERa } \\
\hline Negative & 75 & 51 & 24 & $<0.001$ & & 0.333 & $<0.001$ \\
\hline Positive & 105 & 36 & 69 & & & & \\
\hline \multicolumn{8}{|l|}{$P R$} \\
\hline Negative & 75 & 50 & 25 & $<0.001$ & & 0.31 & $<0.001$ \\
\hline Positive & 105 & 37 & 68 & & & & \\
\hline \multicolumn{8}{|l|}{ HER-2 } \\
\hline Negative & 124 & 53 & 71 & 0.025 & & -0.166 & 0.025 \\
\hline Positive & 56 & 34 & 22 & & & & \\
\hline \multicolumn{8}{|l|}{ E-cadherin } \\
\hline Negative & 33 & 24 & 9 & 0.002 & & 0.231 & 0.002 \\
\hline Positive & 147 & 63 & 84 & & & & \\
\hline \multicolumn{8}{|l|}{ Slug } \\
\hline Negative & 170 & 86 & 84 & 0.019 & & 0.186 & 0.012 \\
\hline Positive & 10 & 1 & 9 & & & & \\
\hline \multicolumn{8}{|l|}{ Vimentin } \\
\hline Negative & 165 & 84 & 81 & 0.022 & & 0.171 & 0.022 \\
\hline Positive & 15 & 3 & 12 & & & & \\
\hline \multicolumn{8}{|l|}{ SMA } \\
\hline Negative & 169 & 85 & 84 & 0.039 & & 0.154 & 0.039 \\
\hline
\end{tabular}


Table 1 Correlation between TRPS1 expression and the clinicopathologic characteristics of breast cancer patients (Continued)

\begin{tabular}{|c|c|c|c|c|c|c|}
\hline Positive & 11 & 2 & 9 & & & \\
\hline \multicolumn{7}{|l|}{$\beta$-catenin } \\
\hline Negative & 67 & 42 & 25 & 0.003 & 0.221 & 0.003 \\
\hline Positive & 113 & 45 & 68 & & & \\
\hline \multicolumn{7}{|l|}{ ERB } \\
\hline$\leq 2$ & 92 & 55 & 37 & 0.001 & 0.242 & 0.001 \\
\hline$>2$ & 87 & 31 & 56 & & & \\
\hline \multicolumn{7}{|l|}{ IMP3 } \\
\hline Negative & 157 & 77 & 80 & 0.618 & & \\
\hline Positive & 23 & 10 & 13 & & & \\
\hline
\end{tabular}

Table 2 Correlation between TRPS1 expression and molecular markers in ERa positive breast cancer patients

\begin{tabular}{|c|c|c|c|c|c|c|c|}
\hline \multirow[t]{2}{*}{ Characteristics } & \multirow[t]{2}{*}{$\mathbf{n}$} & \multicolumn{2}{|c|}{ TRPS1 expression } & \multirow[t]{2}{*}{$P$ value } & \multirow{2}{*}{$\begin{array}{l}\text { Spearman } \\
\text { Correlation }\end{array}$} & \multirow[t]{2}{*}{ Value $(r)$} & \multirow[t]{2}{*}{$P$ value } \\
\hline & & Negative & Positive & & & & \\
\hline \multicolumn{8}{|l|}{ Age(y) } \\
\hline$\leq 50$ & 42 & 9 & 33 & 0.023 & & -0.221 & 0.023 \\
\hline$>50$ & 63 & 27 & 36 & & & & \\
\hline \multicolumn{8}{|l|}{ Expression of P53 } \\
\hline Negative & 45 & 23 & 22 & 0.002 & & 0.307 & 0.001 \\
\hline Positive & 60 & 13 & 47 & & & & \\
\hline \multicolumn{8}{|l|}{ E-cadherin } \\
\hline Negative & 16 & 13 & 3 & $<0.001$ & & 0.42 & $<0.001$ \\
\hline Positive & 89 & 23 & 66 & & & & \\
\hline \multicolumn{8}{|l|}{ Slug } \\
\hline Negative & 102 & 36 & 66 & 0.549 & & & \\
\hline Positive & 3 & 0 & 3 & & & & \\
\hline \multicolumn{8}{|l|}{ Vimentin } \\
\hline Negative & 101 & 36 & 65 & 0.296 & & & \\
\hline Positive & 4 & 0 & 4 & & & & \\
\hline \multicolumn{8}{|l|}{ SMA } \\
\hline Negative & 101 & 36 & 65 & 0.296 & & & \\
\hline Positive & 4 & 0 & 4 & & & & \\
\hline \multicolumn{8}{|l|}{$\beta$-catenin } \\
\hline Negative & 34 & 19 & 15 & 0.001 & & 0.315 & 0.001 \\
\hline Positive & 71 & 17 & 54 & & & & \\
\hline \multicolumn{8}{|l|}{ ER $\beta$} \\
\hline$\leq 2$ & 46 & 21 & 25 & 0.03 & & 0.211 & 0.03 \\
\hline$>2$ & 59 & 15 & 44 & & & & \\
\hline \multicolumn{8}{|l|}{ IMP3 } \\
\hline Negative & 101 & 34 & 67 & 0.605 & & & \\
\hline Positive & 4 & 2 & 2 & & & & \\
\hline
\end{tabular}



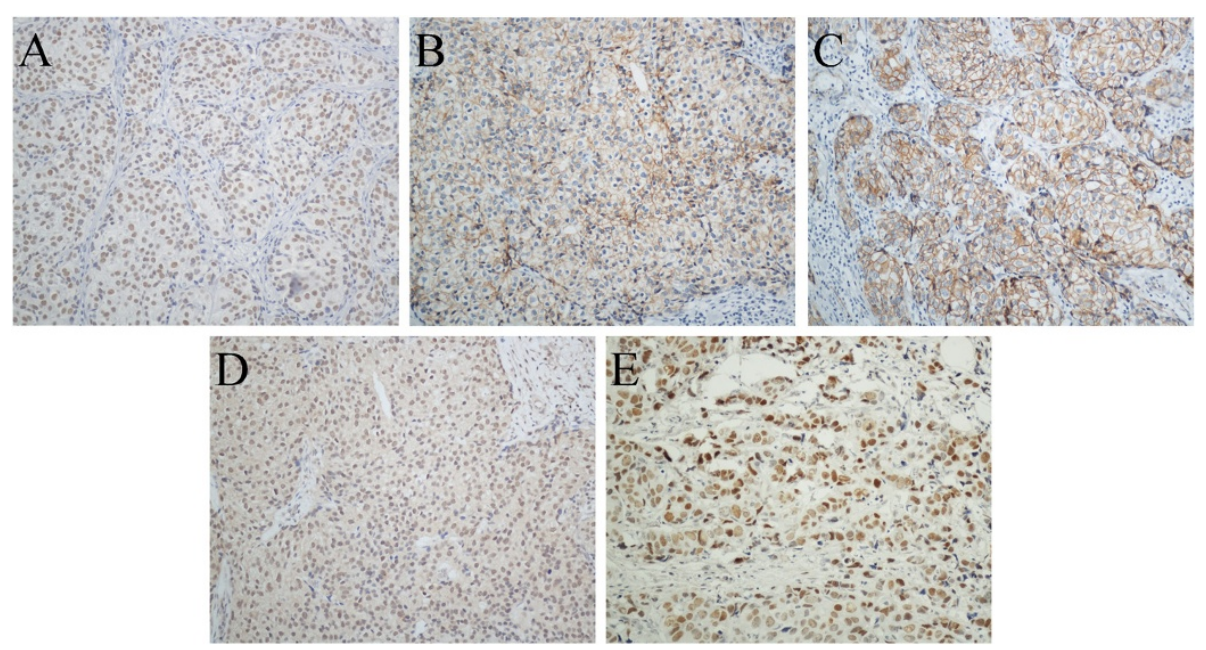

Figure 1 Expression of markers in ERa-positive breast cancer (Magnification 200X). A. Positive nuclear staining for TRPS1, B. Positive membranous staining for E-cadherin, C. Positive membranous staining for $\beta$-catenin, D. Positive nuclear staining for ER $\beta$, and $\mathbf{E}$. Positive nuclear staining for P53.

Table 3 Correlation between TRPS1 expression and molecular markers in ERa negative breast cancer patients

\begin{tabular}{|c|c|c|c|c|c|c|c|}
\hline \multirow[t]{2}{*}{ Characteristics } & \multirow[t]{2}{*}{$\mathbf{n}$} & \multicolumn{2}{|c|}{ TRPS1 expression } & \multirow[t]{2}{*}{$P$ value } & \multirow{2}{*}{$\begin{array}{l}\text { Spearman } \\
\text { Correlation }\end{array}$} & \multirow[t]{2}{*}{ Value $(r)$} & \multirow[t]{2}{*}{$P$ value } \\
\hline & & Negative & Positive & & & & \\
\hline \multicolumn{8}{|l|}{ Age(y) } \\
\hline$\leq 50$ & 28 & 17 & 11 & 0.296 & & & \\
\hline$>50$ & 47 & 34 & 13 & & & & \\
\hline \multicolumn{8}{|l|}{ Expression of P53 } \\
\hline Negative & 27 & 17 & 10 & 0.483 & & & \\
\hline Positive & 48 & 34 & 14 & & & & \\
\hline \multicolumn{8}{|l|}{ E-cadherin } \\
\hline Negative & 17 & 11 & 6 & 0.741 & & & \\
\hline Positive & 58 & 40 & 18 & & & & \\
\hline \multicolumn{8}{|l|}{ Slug } \\
\hline Negative & 68 & 50 & 18 & 0.004 & & 0.369 & 0.001 \\
\hline Positive & 7 & 1 & 6 & & & & \\
\hline \multicolumn{8}{|l|}{ Vimentin } \\
\hline Negative & 64 & 48 & 16 & 0.003 & & 0.362 & 0.001 \\
\hline Positive & 11 & 3 & 8 & & & & \\
\hline \multicolumn{8}{|l|}{ SMA } \\
\hline Negative & 68 & 49 & 19 & 0.031 & & 0.271 & 0.019 \\
\hline Positive & 7 & 2 & 5 & & & & \\
\hline \multicolumn{8}{|l|}{$\beta$-catenin } \\
\hline Negative & 33 & 23 & 10 & 0.78 & & & \\
\hline Positive & 42 & 28 & 14 & & & & \\
\hline \multicolumn{8}{|l|}{ ER $\beta$} \\
\hline$\leq 2$ & 46 & 34 & 12 & 0.167 & & & \\
\hline$>2$ & 29 & 17 & 12 & & & & \\
\hline \multicolumn{8}{|l|}{ IMP3 } \\
\hline Negative & 56 & 43 & 13 & 0.005 & & 0.323 & 0.005 \\
\hline Positive & 19 & 8 & 11 & & & & \\
\hline
\end{tabular}




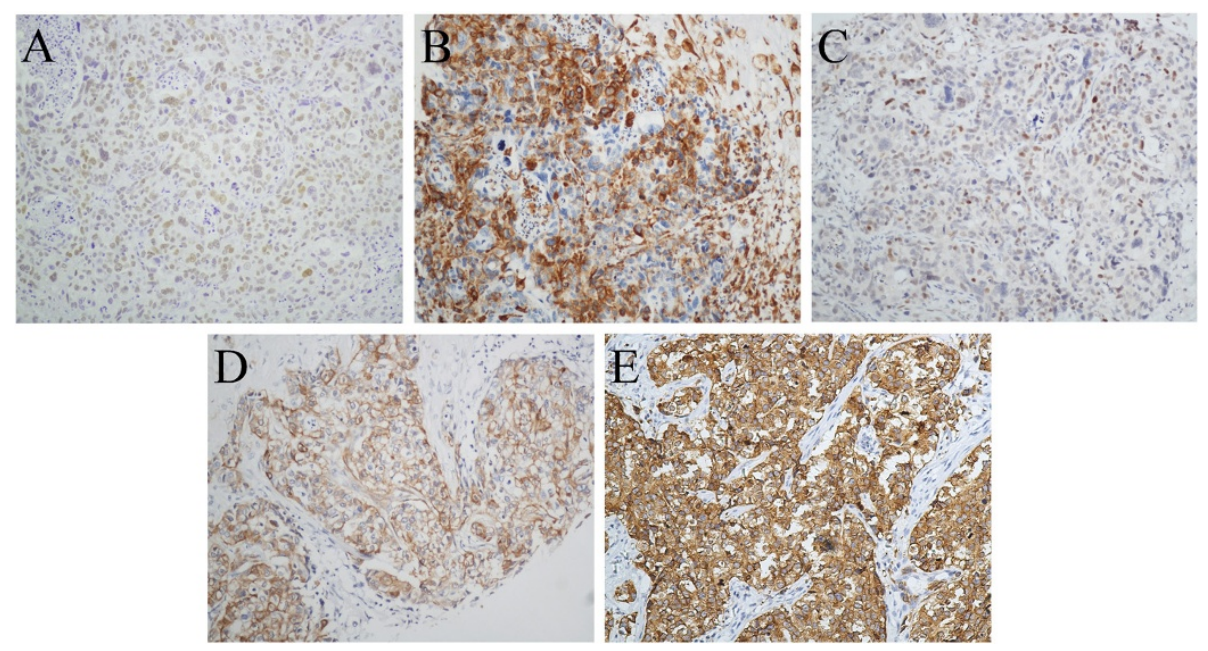

Figure 2 Expression of markers in ERa-negative breast cancer (Magnification 200X). A. Positive nuclear staining for TRPS1, B. Positive cytoplasmic staining for vimentin, C. Positive nuclear staining for slug. D. Positive cytoplasmic staining for SMA, and E. Positive cytoplasmic staining for IMP3.

Next, we investigated the expression of TRPS1 in primary human breast cancer samples and explored its association with major breast tumour histological specialties and patients' clinical characteristics. TRPS1 was positively associated with ER and PR expressions and negatively associated with HER2 status, which is consistent with previous study [6].

When the cut-off level score for TRPS1 to be positive is 1 , the TRPS1 was not remarkably associated with the tumour grade, pathological stage, tumour size and lymph node metastasis. However, upon changing the cut-off level score of TRPS1 to be positive as $\geq 2$, TRPS1 was found to be positively associated with lymph node metastasis and P53 status (data not shown).

However, previous studies showed that higher TRPS1 expression, when analysed using univariate and multivariate models, predicted better overall survival (OS) and disease-free survival (DFS) in a subgroup of ER $\alpha+$, stage I/II breast cancer patients who received endocrine therapy only [32]. Recent studies have also confirmed that high TRPS1 expression was significantly associated with lymph node metastasis and higher pathological stage of patients with colon cancer [14]. All these findings support our hypothesis that TRPS1 may not merely be an indicator of better prognosis as shown in other studies. However, further research using larger patient cohort and more breast cancer cell lines is required to elucidate this contradictory result.

Epithelial cancer cells attain mesenchymal features that make them easier to invade the surrounding tissues and metastasise during EMT process. We used IHC to analyse these markers in 180 patients. Although TRPS1 was significantly associated with E-cadherin and $\beta$-catenin, it was also positively associated with mesenchymal markers such as vimentin, SMA, and slug. The above data did not comply with previous results that TRPS1 inhibits EMT process in breast cancer progression [12]. Hence, we divided the patients into two groups as ER $\alpha$-positive and ER $\alpha$ negative and reanalysed these EMT markers. Surprisingly, in ER $\alpha$-positive breast cancer, we found TRPS1 to be positively associated with E-cadherin and $\beta$-catenin status with no significant correlation with any of the mesenchymal markers. Consistent with our hypothesis, significant association was also found between TRPS1 expression and Ecadherin expression in ER $\alpha$ + breast cancer cases [32]. In ER $\alpha$-negative breast cancer, we found TRPS1 to be positively associated with vimentin, SMA and slug. TRPS1 was also found to be positively related with IMP3, which is expressed preferentially in triple negative breast cancers (TNBC). IMP3 is a member of insulin-like growth factor II (IGF-II) mRNA-binding proteins family. It contributes to the migration and invasion of TNBC cells. Thus, TRPS1 may be associated with the migration, invasion, and EMT in ER $\alpha$-negative breast cancer cells. Ligand-activated ER $\alpha$ could suppress slug transcription through direct association with the slug promoter. Human breast cancers, which lack ligand-activated $\mathrm{ER} \alpha$, may then over-express slug that may downregulate E-cadherin and lead to EMT [33]. We found TRPS1 to be associated with different EMT markers by different ER $\alpha$ status, therefore, ER $\alpha$ might play an important role in affecting the relationship between TRPS1 and EMT markers.

Estrogen receptors include estrogen receptor $\alpha(E R \alpha)$ and estrogen receptor $\beta$ (ER $\beta)$. Most studies have provided evidence that ER $\beta$ acts as a negative modulator of ER $\alpha$ and indicates a good prognosis with prolonged DFS [34,35]. Several investigators have found ER $\beta$ expression to be positively correlated with poor prognostic phenotypes such as 
accelerated proliferation and basal phenotype in ER $\alpha$ negative breast cancer [36,37]. We also stained ER $\beta$ and found its expression to be correlated with TRPS1 expression. TRPS1 expression was not regulated by ER signalling since estrogen withdrawal using charcoal-stripped serum did not affect TRPS1 gene or protein expression in ER $\alpha$ positive breast cancer cell lines [32]. Thus, we have assumed that TRPS1 might transcriptionally both regulate genes and affect tumour growth and development to varying degrees.

\section{Conclusions}

There are many possible explanations for the different association between the molecular markers with TRPS1 in $E R \alpha$-positive and ER $\alpha$-negative breast cancer. First, TRPS1 is capable of binding to numerous cofactors of various functions. Second, it may either promote or inhibit carcinoma processing depending on the context and amount of protein present $[38,39]$. Based on the above results, we conclude that TRPS1 is positively associated with E-cadherin and $\beta$-catenin status in ER $\alpha$-positive breast cancer, while it also has a significant association with mesenchymal markers of EMT in ER $\alpha$-negative breast cancer. However, further studies with large number of tumours and breast cancer cell lines are required to validate the precise function of TRPS1 gene in breast cancer.

\section{Abbreviations}

TRPS1: Tricho-rhino-phalangeal syndrome I; EMT: Epithelial to mesenchymal transition; ER: Estrogen receptor; IMP3: Insulin-like growth factor II (IGF-II) mRNA-binding protein 3; TNBC: Triple negative breast cancer; SMA: Smooth muscle actin.

\section{Competing interests}

The authors declare that they have no competing interests.

\section{Authors' contributions}

PS and GZ conceived and designed the overall study. PS performed IHC and wrote the manuscript. $\mathrm{HZ}$ and $\mathrm{XJ}$ performed histological analysis and participated in the collection of data. JH and WL performed $\mathrm{IHC}$ manual assessment and analysis. MJ analysed the data and did the statistical data analyses. All authors read and approved the manuscript for publication.

\section{Author details}

'Department of Pathology, Shandong University School of Medicine, 44\#, Wenhua Xi Road, 250012 Jinan, Shandong, P.R. China. ${ }^{2}$ Department of Pathology, Qilu Hospital of Shandong University, Jinan, PR China.

Received: 9 April 2014 Accepted: 2 June 2014

Published: 16 June 2014

\section{References}

1. Cancer Genome Atlas N: Comprehensive molecular portraits of human breast tumours. Nature 2012, 490:61-70.

2. Preat $F$, Simon $P$, Noel JC: Differences in breast carcinoma immunohistochemical subtypes between immigrant Arab and European women. Diagn Pathol 2014, 9:26.

3. Wang S, Li H, Wang J, Wang D: Expression of microRNA-497 and its prognostic significance in human breast cancer. Diagn Pathol 2013, 8:172.

4. Zhang $Q$, Zhang $Q$, Cong $H$, Zhang $X$ : The ectopic expression of BRCA1 is associated with genesis, progression, and prognosis of breast cancer in young patients. Diagn Pathol 2012, 7:181.
5. Radvanyi L, Singh-Sandhu D, Gallichan S, Lovitt C, Pedyczak A, Mallo G, Gish K, Kwok K, Hanna W, Zubovits J, Armes J, Venter D, Hakimi J, Shortreed J, Donovan M, Parrington M, Dunn P, Oomen R, Tartaglia J, Berinstein NL: The gene associated with trichorhinophalangeal syndrome in humans is overexpressed in breast cancer. Proc Natl Acad Sci U S A 2005, 102:11005-11010.

6. Chen JQ, Litton J, Xiao L, Zhang HZ, Warneke CL, Wu Y, Shen X, Wu S, Sahin A, Katz R, Bondy M, Hortobagyi G, Berinstein NL, Murray JL, Radvanyi L: Quantitative immunohistochemical analysis and prognostic significance of TRPS-1, a new GATA transcription factor family member, in breast cancer. Horm Cancer 2010, 1:21-33.

7. Momeni P, Glockner G, Schmidt O, Von Holtum D, Albrecht B, GillessenKaesbach G, Hennekam R, Meinecke P, Zabel B, Rosenthal A, Horsthemke B, Ludecke $\mathrm{HJ}$ : Mutations in a new gene, encoding a zinc-finger protein, cause tricho-rhino-phalangeal syndrome type I. Nat Genet 2000, 24:71-74.

8. Malik TH, Shoichet SA, Latham P, Kroll TG, Peters LL, Shivdasani RA: Transcriptional repression and developmental functions of the atypical vertebrate GATA protein TRPS1. EMBO J 2001, 20:1715-1725.

9. Napierala D, Sam K, Morello R, Zheng Q, Munivez E, Shivdasani RA, Lee B: Uncoupling of chondrocyte differentiation and perichondrial mineralization underlies the skeletal dysplasia in tricho-rhino-phalangeal syndrome. Hum Mol Genet 2008, 17:2244-2254.

10. Piscopo DM, Johansen EB, Derynck R: Identification of the GATA factor TRPS1 as a repressor of the osteocalcin promoter. J Biol Chem 2009, 284:31690-31703.

11. Chang GT, Steenbeek M, Schippers E, Blok LJ, Van Weerden WM, Van Alewijk DC, Eussen BH, Van Steenbrugge GJ, Brinkmann AO: Characterization of a zinc-finger protein and its association with apoptosis in prostate cancer cells. J Natl Cancer Inst 2000, 92:1414-1421.

12. Stinson S, Lackner MR, Adai AT, Yu N, Kim HJ, O'Brien C, Spoerke J, Jhunjhunwala S, Boyd Z, Januario T, Newman RJ, Yue P, Bourgon R, Modrusan Z, Stern HM, Warming S, de Sauvage FJ, Amler L, Yeh RF, Dornan D: TRPS1 targeting by miR-221/222 promotes the epithelial-tomesenchymal transition in breast cancer. Sci Signal 2011, 4:ra41.

13. Chang GT, Jhamai M, Van Weerden WM, Jenster G, Brinkmann AO: The TRPS1 transcription factor: androgenic regulation in prostate cancer and high expression in breast cancer. Endocr Relat Cancer 2004, 11:815-822.

14. Hong J, Sun J, Huang T: Increased expression of TRPS1 affects tumor progression and correlates with patients' prognosis of colon cancer. BioMed Res Int 2013, 2013:454085.

15. Hu J, Su P, Jia M, Wu X, Zhang H, Li W, Zhou G: TRPS1 expression promotes angiogenesis and affects VEGFA expression in breast cancer. Exp Biol Med (Maywood) 2014, 239:423-429.

16. Gai Z, Zhou G, Itoh S, Morimoto Y, Tanishima H, Hatamura I, Uetani K, Ito M, Muragaki Y: Trps1 functions downstream of Bmp7 in kidney development. J Am Soc Nephrol 2009, 20:2403-2411.

17. Itoh S, Kanno S, Gai Z, Suemoto H, Kawakatsu M, Tanishima H, Morimoto Y, Nishioka K, Hatamura I, Yoshida M, Muragaki Y: Trps1 plays a pivotal role downstream of Gdf5 signaling in promoting chondrogenesis and apoptosis of ATDC5 cells. Genes Cells 2008, 13:355-363.

18. Thiery JP: Epithelial-mesenchymal transitions in development and pathologies. Curr Opin Cell Biol 2003, 15:740-746.

19. Thiery JP: Epithelial-mesenchymal transitions in tumour progression. Nat Rev Cancer 2002, 2:442-454

20. Kalluri $R$, Weinberg RA: The basics of epithelial-mesenchymal transition. J Clin Invest 2009, 119:1420-1428.

21. Thiery JP, Acloque H, Huang RY, Nieto MA: Epithelial-mesenchymal transitions in development and disease. Cell 2009, 139:871-890.

22. Kang Y, Massague J: Epithelial-mesenchymal transitions: twist in development and metastasis. Cell 2004, 118:277-279.

23. Blanco MJ, Moreno-Bueno G, Sarrio D, Locascio A, Cano A, Palacios J, Nieto MA: Correlation of Snail expression with histological grade and lymph node status in breast carcinomas. Oncogene 2002, 21:3241-3246.

24. Prasad CP, Rath G, Mathur S, Bhatnagar D, Parshad R, Ralhan R: Expression analysis of E-cadherin, Slug and GSK3beta in invasive ductal carcinoma of breast. BMC Cancer 2009, 9:325.

25. Hsu HP, Shan YS, Jin YT, Lai MD, Lin PW: Loss of E-cadherin and betacatenin is correlated with poor prognosis of ampullary neoplasms. J Surg Oncol 2010, 101:356-362.

26. Kim K, Lu Z, Hay ED: Direct evidence for a role of beta-catenin/LEF-1 signaling pathway in induction of EMT. Cell Biol Int 2002, 26:463-476. 
27. Xiang L, Su P, Xia S, Liu Z, Wang Y, Gao P, Zhou G: ABCG2 is associated with HER-2 expression, lymph node metastasis and clinical stage in breast invasive ductal carcinoma. Diagn Pathol 2011, 6:90.

28. Su P, Zhang Q, Yang Q: Immunohistochemical analysis of Metadherin in proliferative and cancerous breast tissue. Diagn Pathol 2010, 5:38.

29. Sung R, Kang L, Han JH, Choi JW, Lee SH, Lee TH, Park SH, Kim HJ, Lee ES, Kim YS, Choi YW, Park SM: Differential Expression of E-Cadherin, betaCatenin, and S100A4 in Intestinal Type and Nonintestinal Type Ampulla of Vater Cancers. Gut and liver 2014, 8:94-101.

30. Hammond ME, Hayes DF, Dowsett M, Allred DC, Hagerty KL, Badve S, Fitzgibbons PL, Francis G, Goldstein NS, Hayes M, Hicks DG, Lester S, Love R, Mangu PB, McShane L, Miller K, Osborne CK, Paik S, Perlmutter J, Rhodes A, Sasano H, Schwartz JN, Sweep FC, Taube S, Torlakovic EE, Valenstein P, Viale $G$, Visscher D, Wheeler T, Williams RB, et al: American Society of Clinical Oncology/College Of American Pathologists guideline recommendations for immunohistochemical testing of estrogen and progesterone receptors in breast cancer. J Clin Oncol 2010, 28:2784-2795.

31. Sethi S, Sarkar FH, Ahmed Q, Bandyopadhyay S, Nahleh ZA, Semaan A, Sakr W, Munkarah A, Ali-Fehmi R: Molecular markers of epithelial-tomesenchymal transition are associated with tumor aggressiveness in breast carcinoma. Trans/ Oncol 2011, 4:222-226.

32. Chen JQ, Bao Y, Lee J, Murray JL, Litton JK, Xiao L, Zhou R, Wu Y, Shen XY, Zhang H, Sahin AA, Katz RL, Bondy ML, Berinstein NL, Hortobagyi GN, Radvanyi LG: Prognostic value of the trichorhinophalangeal syndrome-1 (TRPS-1), a GATA family transcription factor, in early-stage breast cancer. Ann Oncol 2013, 24:2534-2542.

33. Ye Y, Xiao Y, Wang W, Yearsley K, Gao JX, Barsky SH: ERalpha suppresses slug expression directly by transcriptional repression. Biochem J 2008, 416:179-187.

34. Paruthiyil S, Parmar H, Kerekatte V, Cunha GR, Firestone GL, Leitman DC: Estrogen receptor beta inhibits human breast cancer cell proliferation and tumor formation by causing a G2 cell cycle arrest. Cancer Res 2004, 64:423-428.

35. Lazennec G: Estrogen receptor beta, a possible tumor suppressor involved in ovarian carcinogenesis. Cancer Lett 2006, 231:151-157.

36. Skliris GP, Leygue E, Curtis-Snell L, Watson PH, Murphy LC: Expression of oestrogen receptor-beta in oestrogen receptor-alpha negative human breast tumours. Br J Cancer 2006, 95:616-626.

37. Jensen EV, Cheng G, Palmieri C, Saji S, Makela S, Van Noorden S, Wahlstrom T, Warner M, Coombes RC, Gustafsson JA: Estrogen receptors and proliferation markers in primary and recurrent breast cancer. Proc Natl Acad Sci U S A 2001, 98:15197-15202.

38. Fantauzzo KA, Tadin-Strapps M, You Y, Mentzer SE, Baumeister FA, Cianfarani S, Van Maldergem L, Warburton D, Sundberg JP, Christiano AM: A position effect on TRPS1 is associated with Ambras syndrome in humans and the Koala phenotype in mice. Hum Mol Genet 2008, 17:3539-3551.

39. Wuelling M, Kaiser FJ, Buelens LA, Braunholz D, Shivdasani RA, Depping R, Vortkamp A: Trps1, a regulator of chondrocyte proliferation and differentiation, interacts with the activator form of Gli3. Dev Biol 2009, 328:40-53.

doi:10.1186/1746-1596-9-119

Cite this article as: Su et al:: Association of TRPS1 gene with different EMT markers in ERa-positive and ERa-negative breast cancer. Diagnostic Pathology 2014 9:119.

\section{Submit your next manuscript to BioMed Central and take full advantage of:}

- Convenient online submission

- Thorough peer review

- No space constraints or color figure charges

- Immediate publication on acceptance

- Inclusion in PubMed, CAS, Scopus and Google Scholar

- Research which is freely available for redistribution

Submit your manuscript at www.biomedcentral.com/submit
C Biomed Central 